\title{
The Book of the Twelve - One Book or Many?
}

\author{
Metz Conference Proceedings 5-7 November 2015 \\ Ed. by Elena Di Pede and Donatella Scaiola
}

[Das Zwölfprophetenbuch - ein Buch oder viele? Tagungsband zur Konferenz in Metz. 5.-7. November 2015.]

Veröffentlicht auf Englisch.

Die zwölf Propheten bieten sowohl aus exegetischer als auch aus theologischer Perspektive ein interessantes Forschungsfeld. Das Zwölfprophetenbuch war Thema einer internationalen Tagung, die im November 2015 an der Université de Lorraine in Metz stattfand; dieser Tagungsband präsentiert deren Ergebnisse. Das grundsätzliche Ziel war die Untersuchung der Verbindung zwischen Theorie, ungenannten Voraussetzungen und exegetischer Analyse. Zwei bestimmte Gebiete wurden während der Tagung eingehend betrachtet: Sollte das Zwölfprophetenbuch als ein Buch gelesen werden, als eine Anthologie oder als etwas gänzlich anderes? Und wie sollten die einzelnen Texte interpretiert werden und/oder wie sollten bestimmte Texte analysiert werden? Eine Besonderheit der Tagung war der Kontrast, der zwischen den teilnehmenden Autoren und deren exegetischen Annahmen auszumachen war.

\section{Inhaltsübersicht}

Donatella Scaiola/Elena Di Pede: Introduction - Ehud Ben Zvi: Remembering Twelve Prophetic Characters from the Past James D. Nogalski: The Book of the Twelve Is Not a Hypothesis - Yair Zakovitch: Do the Last Verses of Malachi (Mal 3:22-24) Have a Canonical Function? A Biblical Puzzle - Innocent Himbaza: Les thèmes théologiques de Malachie et le concept du livre des XII Prophètes - Guido Benzi: Rhetorical Analysis, Interpretation, and Location of Hosea 1-3 in its Relation to the Twelve Prophets Scroll - Hervé Tremblay: Vox clamantis in deserto? L'enseignement d'Amos sur la justice sociale dans le contexte de la théorie de l'unité des douze - Claude Lichtert: Entre rappels et renversements: les particularités littéraires et théologiques du récit de Jonas - Christophe L. Nihan: Remarques sur la question de I'"unité« des XII - Jean-Daniel Macchi: Ésaïe dans les XII:

ISBN 978-3-16-154942-7

DOI 10.1628/978-3-16-154942-7

eBook PDF 74,00€

ISBN 978-3-16-154553-5

fadengeheftete Broschur 74,00€

Elena Di Pede Born 1972; 1999 license in biblical philology, 2000 in theology; 2004 PhD; 2008-16 post-doctorate (financed by the FNRS [Fonds National de la Recherche Scientifique - Belgium]) at the Faculty of Theology of the Université catholique de Louvain, Louvain-la-Neuve; currently professor at the Université de Lorraine-Metz (France), and visiting professor at the Centre Sèvres - Jesuit faculties of Paris.

Donatella Scaiola Born 1958; bachelor of theology; license in biblical sciences; PhD in biblical sciences; since 1990 she has taught at numerous institutions of higher religious studies and theological faculties; currently she is full professor at the Pontificia Università Urbaniana in Rome, and visiting professor at the Theological Faculty in Milan.

Jetzt bestellen:

https://mohrsiebeck.com/buch/the-book-of-the-twelve-one-book-or-many-9783161549427?no_cache=1

order@mohrsiebeck.com

Telefon: +49 (0)7071-923-17

Telefax: $+49(0) 7071-51104$ 